УДК 620.2:339.543

https://doi.org/10.35546/kntu2078-4481.2021.4.21

О.М. ВЕРБИЦЬКИЙ

Херсонський національний технічний університет ORCID: 0000-0003-2178-1283

О.П. ДОМБРОВСЬКА

Херсонський національний технічний університет ORCID: 0000-0002-8007-7360

Г.A. TIXOCOBA

Херсонський національний технічний університет ORCID: 0000-0003-1163-6074

Л.А. ЧУРСІНА

Херсонський національний технічний університет ORCID: 0000-0002-8076-9666

А.В. НАГОРНА

Херсонський національний технічний університет ORCID: 0000-0001-6874-3490

\title{
АСПЕКТ ЗАПРОВАДЖЕННЯ СПЕЦАЛЬНИХ СПРОЩЕНЬ МИТНОГО ОФОРМЛЕННЯ АВТОРИЗОВАНИХ ЕКОНОМІЧНИХ ОПЕРАТОРІВ
}

Предметом вивчення в статті $\epsilon$ вимоги до пломбування контейнерів з вантажем, щуо готуються до відправлення за кордон авторизованими економічними операторами.

Мета роботи полягає в аналізі вимог та вузьких місиьь у техніці реалізації права підприємства авторизованого економічного оператора самостійно накладати пломбувальні пристрої на транспортні засоби.

Зазначено, щчо конструкиія універсальних, рефрижераторних та танк-контейнерів, а також конструкиія стрижневих пломб не виключають можливості несанкиіонованого доступу до вантажу без видимих ознак розкриття контейнера. Зауважено, ш⿻ існує понад десяти способів відкриття опломбованих контейнерів без пошкодження захисних пломб за відсутності ознак відкриття й несанкиіонованого доступу до вантажу.

В статті показано, щз самостійне накладання пломбувальних пристроїв на транспортні засоби потребує від підприємств-користувачів забезпечення виконання вимог міжнародних стандартів щуодо організаџіï та контролю цьвого прочесу. Наголошено на важливості виконання всіх пунктів стандарту ISO 17712:2013 задля гарантування безпеки міжнародних відправлень вантажів авторизованими економічними операторами.

Для підвищення інформативної та захисної складової пломбувальних пристроїв рекомендовано застосовувати разом із силовими пломбами електронно-навігаџійні пломби або електронно-навігаційні замки.

Разом із тим, доведено, щзо грамотна організація та виконання вимог стандартів й державних нормативних актів щзодо організації самостійного накладання пломб підприємствами дозволить забезпечити безпеку міжнародних відправлень, зменшить ризики порушення митного законодавства та дозволить скоротити час на виконання митних формальностей.

Ключові слова: авторизований економічний оператор, пломбувальний пристрій, охоронна система, контейнер, митні формальності, безпечність міжнародних відправлень.

А.Н. ВЕРБИЦКИЙ

Херсонский национальный технический университет ORCID: 0000-0003-2178-1283

Е.П. ДОМБРОВСКАЯ

Херсонский национальный технический университет ORCID: 0000-0002-8007-7360

А.А. ТИХОСОВА

Херсонский национальный технический университет ORCID: 0000-0003-1163-6074

Л.А. ЧУРСИНА

Херсонский национальный технический университет ORCID: 0000-0002-8076-9666

А.В. НАГОРНАЯ

Херсонский национальный технический университет ORCID: 0000-0001-6874-3490 


\section{АСПЕКТ ВНЕДРЕНИЯ СПЕЦИАЛЬНЫХ УПРОЩЕНИЙ ТАМОЖЕННОГО ОФОРМЛЕНИЯ АВТОРИЗИРОВАННЫХ ЭКОНОМИЧЕСКИХ ОПЕРАТОРОВ}

Предметом изучения в статье являются требования к пломбированию контейнеров с грузом, которые готовятся авторизованными экономическими операторами к отправке за гранииу.

Цель работы состоит в анализе требований и узких мест в технике реализачии права предприятия -авторизованного экономического оператора самостоятельно накладывать пломбировочные устройства на транспортные средства.

Отмечено, что конструкция универсальных, рефрижераторных и танк-контейнеров, а также конструкиия стержневых пломб не исключают возможности несанкиионированного доступа к грузу без видимых признаков вскрытия контейнера. Замечено, что сущзествует более десяти способов вскрытия опломбированных контейнеров без повреждения защитных пломб, отсутствия признаков вскрытия и несанкиионированного доступа к грузу.

В статье показано, что самостоятельное наложение пломбировочных устройств на транспортные средства требует от предприятий - пользователей обеспечения выполнения требований международных стандартов по организации и контролю этого процесса. Отмечена важность выполнения всех пунктов стандарта ISO 17712:2013 для обеспечения безопасности международньх отправлений грузов авторизованными экономическими операторами.

Для повышения информативной и защитной составляющей пломбировочных устройств рекомендуется применять вместе с силовыми пломбами электронно-навигационные пломбы или электронно-навигационные замки.

Вместе с тем доказано, что грамотная организация и выполнение требований стандартов $и$ государственных нормативных актов по организации самостоятельного наложения пломб предприятиями позволит обеспечить безопасность международньх отправлений, уменьшит риски нарушения таможенного законодательства и сократит время на выполнение таможенных формальностей.

Ключевые слова: авторизированный экономический оператор, пломбировочное устройство, охранная система, контейнер, таможенные формальности, безопасность международных отправлений.

O. M. VERBITSKY

Kherson National Technical University ORCID: 0000-0003-2178-1283

O.P. DOMBROVSKA

Kherson National Technical University ORCID: 0000-0002-8007-7360

H.A. TIKHOSOVA

Kherson National Technical University ORCID: 0000-0003-1163-6074

L.A. CHURSINA

Kherson National Technical University ORCID: 0000-0002-8076-9666

A.V. NAHORNA

Kherson National Technical University ORCID: 0000-0001-6874-3490

\section{SPECIAL VIEW ON THE IMPLEMENTATION OF SPECIAL SIMPLIFICATIONS OF CUSTOMS CLEARANCE OF AUTHORIZED ECONOMIC OPERATORS}

The subject of the article is the requirements for the sealing of containers with cargo, which are prepared by authorized economic operators for shipment abroad.

The purpose of the work is to analyze the requirements and bottlenecks in the technique of exercising the right of the enterprise - authorized economic operator to independently impose sealing devices on vehicles.

It is noted that the design of universal, refrigerated and tank-containers, as well as the design of rod seals do not exclude the possibility of unauthorized access to the cargo without visible signs of opening the container. It is noticed that there are more than ten ways to open the sealed containers without damaging the protective seals, no signs of tampering and unauthorized access to the cargo.

The article shows that independent application of sealing devices on vehicles requires from enterprises users to ensure compliance with the requirements of international standards for the organization and control of this process. The importance of fulfilling all the points of ISO 17712:2013 standard for ensuring the security of international cargo shipments by authorized economic operators is noted. 
In order to increase the informative and security component of sealing devices, it is recommended to use electronic navigation seals or electronic navigation locks together with power seals.

At the same time, it has been proved that competent organization and fulfillment of the requirements of standards and state regulations on the organization of independent application of seals by enterprises will ensure security of international shipments, reduce the risks of violation of customs legislation and reduce the time for customs formalities execution.

Key words: authorized economic operator, sealing device, security system, container, customs formalities, security of international shipments.

\section{Постановка проблеми}

Деякий час митне оформлення в Україні характеризувалося громіздкістю процедур, великими обсягами документообігу, серйозними додатковими витратами часу, ресурсів і коштів. Звісно такий тягар відбивався на підвищенні кінцевої вартості імпортованих й експортованих товарів. Традиційні витрати часу i коштів під час митних процедур стримують розвиток зовнішньоекономічної діяльності українських підприємств.

На даний час питання забезпечення прозорості, оперативності та спрощення митних формальностей для підприємств, що беруть участь у зовнішньоекономічній діяльності, а також формування безпечних ланцюгів постачання товарів $\epsilon$ дуже актуальним. Також підвищення конкурентоспроможності вітчизняної продукції на зовнішніх ринках $\epsilon$ нагальною проблемою сьогодення.

Рішення даної проблеми полягає у модернізації й спрощенні митних процедур, а також уніфікації умов ведення бізнесу, що реалізуються у рамках взаємної згоди між країнами Європейської співдружності. Ключовим моментом у модернізації митної практики $є$ впровадження інституту авторизованого економічного оператора у ланцюзі міжнародних товарноекономічних відносин.

\section{Аналіз останніх досліджень і публікацій}

Дослідженню аспектів впровадження програми авторизованого економічного оператора, що здійснюється у рамках євроінтеграційного курсу України, на даний час приділяють значну увагу.

Даному питанню присвячено багато праць таких науковців як В.А. Туржанський, О.О. Павленко, О.Л. Богданова, О.О. Трякіна, С.В. Гармаш, І.В Несторишен.

Однак, впровадження інституту авторизованого економічного оператора та порядку набуття підприємствами статусу такого уповноваженого оператора викликає ще багато питань, які потребують роз'яснення, а також відпрацювання порядку взаємодії учасників процесу.

\section{Формулювання мети дослідження}

Запровадження в Україні інституту авторизованого економічного оператора (AEO) надає суттєвих спрощень у виконанні митних формальностей для підприємств 3 високим ступенем довіри, заощаджує час та ресурси підприємства під час експорту й імпорту товарів, надає можливість українським підприємствам брати участь у формуванні безпечних ланцюгів постачання товарів та сприяє підвищенню їх конкурентоспроможності на зовнішніх ринках.

Метою даної статті є критична оцінка аспекту впровадження у державі інституту АЕО, аналіз вимог до AEO у частині виключного права самостійно накладати пломби на транспортні засоби перед відправленням за кордон без обов'язкового митного огляду товарів, що перевозяться в опломбованому транспортному засобі.

\section{Викладення основного матеріалу дослідження}

Починаючи з серпня 2020 року в Україні активно й поетапно реалізується програма модернізації й спрощення митних процедур та уніфікації умов ведення бізнесу, частиною якої є запровадження в Україні інституту авторизованого економічного оператора.

Відомо, що запровадження в Україні інституту авторизованого економічного оператора (AEO):

- модернізує митне законодавство України, наближуючи його до європейських стандартів;

- сприяє спрощенню та полегшенню міжнародної торгівлі;

- забезпечує участь українських AЕО у формуванні безпечних ланцюгів постачання товарів й підвищує їх конкурентоспроможність як на внутрішньому, так і на зовнішньому ринках.

Набуття статусу АЕО дає можливість підприємствам одержати такі вигоди як:

- спрощене декларування;

- економія часу та коштів під час виконання митних формальностей;

- зниження ризиків у системі митного оформлення;

- право самостійно накладати пломби на транспортні засоби.

Перелік спеціальних спрощень, якими зможе користуватися підприємство визначається типом отриманої авторизації АЕО [1]. 
Набути статус оператора АЕО може будь-яке підприємство-резидент, що виконує будь-яку роль в міжнародному ланцюзі постачання товарів: виробник, експортер, імпортер, митний представник, перевізник, експедитор або утримувач митного складу. Треба лише пройти складний шлях з авторизації.

Залежно від ролі підприємства у міжнародному ланцюзі постачання товарів, підприємство самостійно може обирати один з двох типів авторизації або одночасно авторизацію обох типів:

AEO-C - про надання права на застосування спеціальних спрощень;

АЕО-Б - про підтвердження безпеки та надійності.

Незалежно від типу авторизації АЕО, підприємство отримує право проходити митні формальності в пріоритетному порядку. Під час визначення переліку процедур контролю в автоматизованій системі аналізу та управління ризиками митниці знижується ступінь ризику такого підприємства,

Для транспортування вантажів підприємства зі статусом АЕО користуються спеціальною смугою руху в пунктах пропуску, що дозволяє уникнути зайвих черг на митниці й заощадити час.

Також підприємствам 3 авторизацією «про підтвердження безпеки та надійності» та «про надання права на застосування спеціальних спрощень» надано право накладати пломби спеціального типу, що дозволяє їм здійснювати пломбування без залучення митного органу.

Компанії або підприємства типу «АЕО-С» можуть отримати спрощення на загальну фінансову гарантію, спрощене декларування та митне очищення товарів, за межами митниці.

Компанії зі статусом «АЕО-Б» мають можливість заздалегідь отримувати повідомлення про майбутній огляд товарів і транспортних засобів комерційного призначення на підставі результатів аналізу ризиків. При цьому компанія або підприємство має право вибрати огляд у пункті пропуску через державний кордон України ще до моменту переміщення транспортного засобу.

Після отримання підприємством статусу АЕО його транспортний засіб із товаром проходить пункти контролю «зеленим коридором» із мінімальними перевірками. Транспортному засобу не потрібно заїжджати на митний термінал і проходити процедури відбору проб продукції за участю митного інспектора. Це дозволяє значно заощадити час на митне оформлення, що, зокрема, сприяє підвищенню оборотності запасів і взагалі позитивно впливає на економічні показники підприємства.

Вантажі підприємства АЕО, що експортує товари, оформляються за місцем знаходження підприємства, що, у свою чергу, дає більше гнучкості в плануванні логістики підприємства.

Експортери, які набули статусу AЕО та право самостійно накладати пломби на транспортні засоби, можуть самостійно пломбувати вантажі без необхідності використовувати митні термінали для проходження формальностей. Вантаж у такому разі буде переміщуватись по митній території України до митного пункту пропуску під митним контролем.

Підприємства AЕО можуть подавати спрощену митну декларацію, за якою митниця буде випускати товари за межі митної території України. Оформлення за спрощеною декларацією можливе також для імпортних вантажів оператора AEO.

Таким чином, набуття статусу АЕО надає підприємству багато суттєвих переваг i, хоча процес авторизації є досить тривалою і непростою процедурою, результат набуття статусу AЕО перекриває витрати підприємства й збільшує його конкурентоспроможність.

Треба зазначити, що не тільки трудомісткість операцій процедури авторизації економічного оператора викликає обгрунтовані питання щодо практичної реалізації, не зовсім розкритими залишаються деякі питання технічної реалізації процедур спрощення митного оформлення.

У рамках даної статті хотілося б звернути увагу й більш детально розглянути умови та технічні аспекти реалізації такої переваги авторизації, як «право самостійно накладати пломби на транспортні засоби», а також визначити особливості запровадження зазначених спеціальних спрощень у митній практиці.

12 грудня цього року набуває чинності Наказ Міністерства фінансів України № 568 від 29.10.2021 «Про затвердження Вимог до характеристик пломб спеціального типу, ведення їх обліку та зберігання», яким затверджено: типи пломб спеціального типу, які можуть використовуватися авторизованими підприємствами, вимоги до характеристик пломб та їх технічних специфікацій, до їх обліку із застосуванням відповідного реєстру та зберігання [2].

Відповідно до затверджених Вимог пломби мають відповідати вимогам ДСТУ ISO 17712:2015 «Вантажні контейнери. Ущільнювачі механічні» або ISO 17712:2013 «Freight containers. Mechanical seals» [3].

За рівнем безпеки пломби (пломбувальні пристрої) повинні бути таких типів [3]:

- пломба з високою гарантією безпеки («high security seal»);

- пломба з гарантією безпеки («security seal»);

- індикативна пломба («indicative seal»).

Відповідальність за вибір типу пломб, згідно зазначених вимог, закріплена за самими підприємствами АЕО [2]. 
Згідно переліку вимог, пломби повинні мати такі основні характеристики [2]:

- залишатися неушкодженими та надійно закріпленими під час застосування;

- легко перевірятися щодо цілісності;

- виготовлятися так, щоб будь-яка поломка, втручання або знімання залишали сліди, які легко виявити без застосування спеціальних засобів;

- розроблятися для одноразового застосування;

- мати легко зчитувані унікальні ідентифікаційні номери.

Пломби, що встановлюються оператором АEО, повинні обов'язково відповідати вказаним технічним специфікаціям:

- форма та розміри пломб (або пломбувальних пристроїв) можуть відрізнятися залежно від методу пломбування, але розміри повинні бути такими, щоб забезпечувати легке зчитування їх унікальних ідентифікаційних номерів;

- спосіб нанесення унікальних ідентифікаційних номерів пломб повинен зробити неможливим їх зміну та/або повторне нанесення таких номерів;

- використаний матеріал повинен бути стійким до випадкової поломки і таким, що запобігає підробленню чи повторному застосуванню пломби.

Окрім того, пломба повинна мати унікальний ідентифікаційний номер у форматі UA/0000000000/УУУУУУ, де:

- UA - літерний код України;

- 000000000 - код підприємства відповідно до Єдиного державного реєстру юридичних осіб, фізичних осіб - підприємців та громадських формувань;

- УУУУУУ - реєстраційний номер пломби в порядку зростання, починаючи з одиниці.

На пломбу може бути нанесено зареєстрований знак для товарів і послуг підприємства. Технологія маркування такої пломби повинна забезпечувати розпізнавання нанесених унікальних ідентифікаційних номерів пломб після дії зовнішніх чинників.

Місця встановлення пломб та перелік об’єктів, на які авторизованими операторами можуть бути встановлені пломби спеціального типу визначено Митним кодексом України (МКУ) [1].

Згідно МКУ, пломби спеціального типу накладаються на контейнери, транспортні засоби комерційного призначення, а також на товари, окремі вантажні місця або інші пакунки до моменту подання до митного органу митної декларації. Відомості про такі пломби обов'язково вносяться до митної декларації [1, Ст. 326-1, п.3].

Оскільки підприємства, які отримали авторизацію АЕО, для транспортування вантажів через митний кордон України переважно використовують стандартні контейнери, вибір пломбувальних пристроїв обумовлений конструктивними особливостями цих контейнерів - це механічні пломбувальні пристрої (МПП) - стрижневі або болтові пломби.

Стрижнева (або болтова) пломба (далі по тексту - МПП) - це двокомпонентна болтова пломба, конструкція якої передбачає з'єднання стрижня з блокуючим корпусом, призначена служити захистом від усіх видів впливу, включаючи заздалегідь підготовлені.
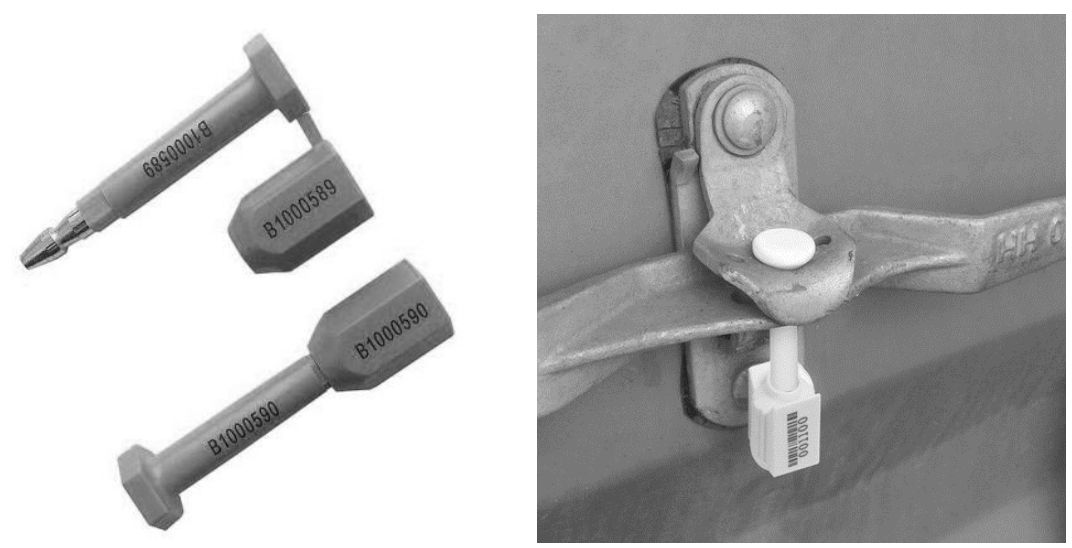

\section{Рис.1. Стрижнева (болтова) пломба: загальний вигляд та приклад встановлення}

Призначення МПП як частини охоронної системи полягає у контролі над несанкціонованим доступом до вантажного контейнера, тобто у встановленні факту несанкціонованого проникнення у вантажний контейнер через двері. МПП можуть бути ефективними лише тоді, коли їх користувачі належним чином вибирають, зберігають, враховують, застосовують, актують зняття та підтримують у 
робочому стані ці пристрої до використання та під час використання. Цей момент підприємство АЕО має чітко усвідомлювати.

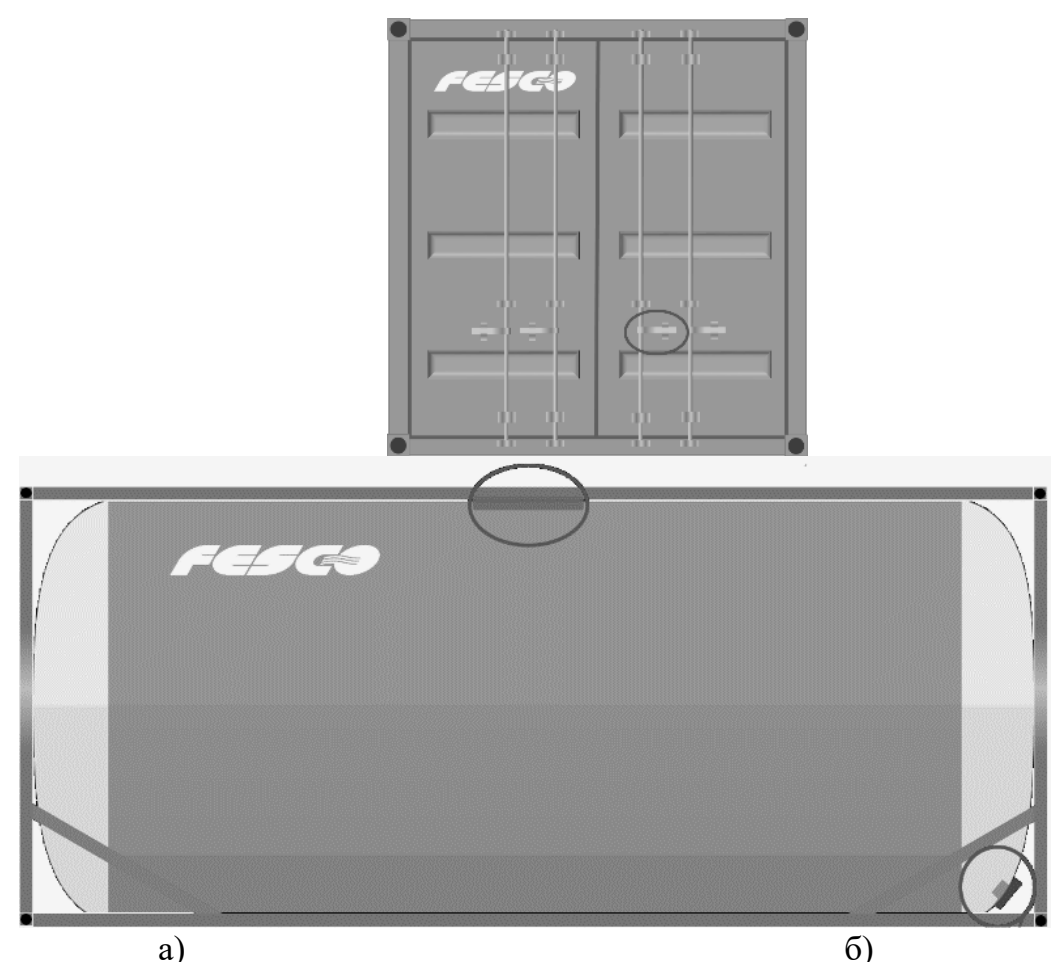

a)

б)

Рис. 2. Місця встановлення пломбувальних пристроїв на контейнери, які застосовуються для міжнародних перевезень: а) на універсальному або рефрижераторному контейнері; б) на танкконтейнері.

Універсальний та рефрижераторний контейнер пломбується як мінімум одним МПП (див. рис. 2a), а при пломбуванні танк-контейнера слід пам'ятати, що встановлюються як мінімум два МПП: на кришці люка й на нижньому зливному отворі (див. рис. 2б).

Вимоги ДСТУ ISO 17712:2015 «Вантажні контейнери. Ущільнювачі механічні» (ISO 17712:2013, IDT) для пломбування контейнерів наказують застосовувати МПП з урахуванням умов експлуатації та зовнішніх факторів, що впливають на пломбу під час транспортування конкретними видами транспорту, а також згідно з вимогами, які пред'являються перевізником відповідного виду транспорту» [3].

МПП повинні бути стійкими до впливу агресивних факторів як тих, що пов'язані з характером вантажу, що транспортується, так і тих, що обумовлені навколишнім середовищем [3]. Конструкція МПП повинна виключати можливість їх розтину шляхом викручування, стягування та збивання без залишення фіксованих слідів розтину [3].

Конструкція МПП повинна унеможливлювати іх розкриття через конструктивні зазори без залишення фіксованих слідів розтину [3].

МПП повинен встановлюватися на об'єкті захисту відповідно до технічної документації на даний МПП i, будучи встановленим, має піддаватися контролю під час замикання запірного механізму (запірних механізмів) на місці [3].

Індикаторний МПП, що має слабкі захисні властивості, слід використовувати лише там, де потрібна лише індикація факту проникнення. У тих випадках, коли визначальною вимогою є фізичний захист, слід використовувати або захисну або посилену пломбу.

Згідно ДСТУ ISO 17712:2015, конструкція МПП повинна забезпечувати одноразове застосування за призначенням та руйнуватися при розтині [3].

Захист механічних пломб від підробки повинен забезпечуватися спеціальними елементами конструкції та захисними технологіями під час ї виготовлення 3 утворенням комплексу ідентифікаційних ознак, що контролюються візуально або спеціальними приладами.

Як вже зазначалось, конструкція МПП повинна виключати можливість розтину шляхом викручування, стягування та збивання без залишення фіксованих слідів розтину, а також унеможливлювати розкриття МПП через конструктивні зазори без залишення фіксованих слідів розтину.

Конструкція МПП повинна виключати можливість розкриття та підробки шляхом часткового розбирання на складові частини, заміни деталей, у тому числі тих, що мають персональний 
ідентифікаційний номер, зміни ідентифікаційного маркування без руйнування конструкції або залишення фіксованих слідів розбирання.

МПП, у конструкції якого використовується пластикове покриття елементів металевих компонентів конструкції, повинен мати товщину таких компонентів, достатню для того, щоб запобігти видаленню пластикового покриття при знятті МПП з вузла замикання контейнера, а також при повторному його закриванні.

Конструкція та маркування МПП повинні бути такими, щоб виробники могли ідентифікувати свої власні вироби [3].

МПП, призначені для використання на вантажних контейнерах, що транспортуються відповідно до митного законодавства, повинні бути сертифіковані та забезпечені індивідуальним маркуванням, яке погоджене із митницею $[1,3]$.

Вхідний контроль таких МПП має проводити споживач, тобто підприємство, яке отримало авторизацію AEO «про підтвердження безпеки та надійності», або «про надання права на застосування спеціальних спрощень» [3]. Відповідальність за збереження МПП, правильність їх встановлення на контейнер та відсутність пошкоджень МПП повністю покладаються на підприємство АЕО.

Підприємства АЕО під час підготовки відправлень міжнародних вантажів мають забезпечувати: збереженість вантажу у пломбованих контейнерах; унеможливлювання несанкціонованого доступу до вантажу сторонніх осіб; надійне пломбування контейнерів; збереженість МПП на місці встановлення; охорону транспортного засобу (особливо контейнера) від можливого випадкового, або навмисного пошкодження, яке може призвести до пошкодження або крадіжки вантажу; організацію швидкого та безпечного транспортування вантажів до митного пункту пропуску.

Для реалізації зазначеного підприємство АЕО має вжити спеціальних і достатніх заходів, аби гарантувати виконання вимог Наказу Міністерства фінансів України № 568 та ДСТУ ISO 17712:2015 [2, 3].

Серед відомих методів захисту МПП від навмисного втручання найбільш ефективним є розробка внутрішньовідомчих інструкцій користувача 3 використання МПП. Інструкції з використання МПП мають включати: порядок отримання МПП від їх виробника, умови зберігання МПП перед встановленням і контроль встановлення МПП тощо [3].

Слід пам'ятати, що різні типи МПП по-різному свідчать про несанкціоноване втручання. Рекомендується, щоб користувачі пройшли навчання з контролю пломбувальних пристроїв та виявлення несанкціонованого втручання.

Особливу увагу треба приділяти зберіганню МПП, яке повинно здійснюється підприємством із виключенням несанкціонованого доступу осіб, що не уповноважені підприємством, на їх зберігання, та забезпечити безперешкодний доступ працівникам митних органів до місця зберігання пломб.

Згідно положень ДСТУ ISO 17712:2015, підприємства AЕО повинні самостійно замикати усі завантажені трейлери та контейнери на місці завантаження, використовуючи сертифіковані МПП [3].

Підприємства AEO повинні регулярно проводити перевірки для підтвердження ефективності вжитих заходів безпеки, включаючи перевірку ідентифікаційних даних водіїв у разі потреби [3].

Виробники пломб та пломбуючих пристроїв повинні проводити внутрішні випробування всіх типів пломбуючих пристроїв, що використовуються на контейнерах у реальних умовах, які можуть зустрітися під час їх транспортування. Звісно, умови тестування МПП можуть бути штучно створені у лабораторії, проте вплив на МПП таких умов має бути максимально наближеним до умов реальної довготривалої експлуатації МПП на транспортному засобі.

У склад таких випробувань обов'язково повинні входити:

- механічні випробування МПП;

- випробування на стійкість до зовнішніх факторів, що впливають на МПП під час експлуатації;

- випробування на стійкість до несанкціонованого розтину та підробки.

Підприємства-користувачі МПП мають законне право та повинні запитувати виробника пломбуючих пристроїв про проведення виробником таких випробувань, вивчити й проаналізувати результати таких випробувань. Встановлювати на транспортний засіб дозволено лише сертифіковані МПП, тому, підприємство АЕО повинне пересвідчитись про наявність сертифікату відповідності пломбувальних пристроїв у виробника.

Митні органи здійснюють контроль за дотриманням підприємствами АЕО порядку обліку пломб, встановленого у відповідності із законодавством України з питань митної справи.

Підприємства-користувачі МПП повинні пам'ятати, що під час транспортування контейнеру виробник МПП не несе відповідальності за збереження МПП. Підприємства-користувачі МПП також повинні пам'ятати, що існує понад десять способів відкриття транспортних контейнерів, при чому МПП залишається без ознак відкриття й узагалі може не містити на собі слідів ушкодження [4]. Факт несанкціонованого відкриття контейнеру може бути виявлений надто пізно, а митники не зобов'язані під час проходження митного контролю відкривати опломбований АЕО контейнер для перевірки вантажу. 
Тому, підприємство разом із митницею повинно ретельно відпрацювати технологію доставляння вантажів у контейнерах до митного пункту пропуску для того, щоб запобігти в майбутньому порушенню митного законодавства України щодо транспортування й митного декларування вантажів авторизованими економічними операторами.

Меті запобігання порушенню митного законодавства України щодо транспортування й митного декларування вантажів авторизованими економічними операторами може послужити такий захід, як використання електронних навігаційних пломб (ЕНП). Ідея використання таких пломбуючих пристроїв полягає у здійснюванні перевезень із застосуванням ЕНП та використанням системи відстеження, що забезпечує збір, обробку, зберігання та передачу в автоматичному режимі даних про місцезнаходження та збереження вантажів.

Ідея використання ЕНП не є новою, приклади ії застосування для забезпечення відстежуваності руху та недоторканості товарів вже відомі, а також відомі результати впровадження [5]. Так, у липні 2013 року в межах пілотного проекту в зоні діяльності Південної митниці було проведено експеримент із використання електронних замків із функцією GPS - GSM навігації при ввезенні товарів та транспортних засобів на митну територію України [5]. Електронні замки застосовувалися під час переміщення транзитних транспортних засобів із товарами, які весь час перебували під митним контролем. Електронні замки встановлювалися на контейнери, а інформація з електронних замків передавалася в режимі онлайн до моніторингового центру Міндоходів, де опрацьовувалася Єдиною автоматизованою інформаційною системою [6].

Електронні замки встановлювалися уповноваженими працівниками митниць при в’їзді транспортного засобу у режимі «транзит» на територію України, а знімалися працівниками митниці, через яку транспортний засіб із товаром виїжджав з території України.

Експеримент із використанням електронних замків з функцією GPS-GSM-навігації виявив наступні переваги: електронний замок вирізняється багаторазовим використанням і здатністю миттєво передавати сигнали тривоги; спеціально розроблене програмне забезпечення дає можливість отримувати від електронного замку максимум інформації про переміщення вантажу: місце його знаходження (траса, населений пункт), стан (закритий чи відкритий) і навіть про швидкість руху автомобіля 3 вантажем [6].

За одержаними позитивними результатами експерименту Міністерство доходів і зборів розробило Порядок використання електронних замків з функцією GPS-GSM навігації й дало «добро» на впровадження цієї технології [7]. Проте, масовому застосуванню таких пристроїв на транспортних засобах, що перевозять вантажі у режимі транзиту, заважає досить висока вартість одного електронного замка (395 долл. США, що значно дорожче, ніж вартість МПП) та обмеження, викликані можливостями вбудованого акумулятора [8].

Тому, використання електронних замків з функцією GPS-GSM-навігації при транспортуванні транзитних вантажів не набуло в Україні поширення.

Тим не менш, електронні замки або ЕНП можуть бути застосовані підприємствами AЕО, як додатковий засіб гарантування недоторканості вантажу під час його транспортування територією України до митниці. ЕНП разом із МПП здатні збільшити рівень захисту товарів, що переміщуються у закритих контейнерах, й значно підвищити інформаційну безпеку недоторканості міжнародних відправлень.

\section{Висновки}

На нашу думку, застосування електронних навігаційних пломб разом із механічними пломбувальними пристроями є перспективним рішенням, яке дозволить підприємствам АЕО краще реалізувати право авторизованого оператора міжнародної економічної діяльності самостійно накладати пломби на транспортні засоби, знизити ризики і гарантувати надійність пломбування відправлених вантажів, і таким чином покращити й прискорити процес митного проходження вантажів.

\section{Список використаної літератури}

1. Митний кодекс України. URL: zakon.rada.gov.ua/laws/show/4495-17\#Text (дата звернення: 21.11.2021).

2. Про затвердження Вимог до характеристик пломб спеціального типу, ведення їх обліку та зберігання: Наказ Міністерства фінансів України № 568 від 29.10.2021 URL: https://mof.gov.ua/storage/files/\%D0\%9D\%D0\%B0\%D0\%BA\%D0\%B0\%D0\%B7(9).pdf

3. ДСТУ ISO 17712:2015. Вантажні контейнери. Ущільнювачі механічні. [Чинний від 2016-01-01].] Київ, 2001. 24 с. (Інформація та документація). URL: http://online.budstandart.com/ua/catalog/docpage.html?id_doc $=96072$
4. E-seal
worldwide
container
tracking
inspection
seal.
URL: https://www.youtube.com/watch?v=wqz99bFYENY

5. Транзитні вантажі 3 електронними

замками. URL: http://tr.sfs.gov.ua/media-ark/newsark/117473.html 
6. Електронні засоби 3 функцією GPS-GSM-навігації: i контролюють, i інформують. URL: http://www.visnuk.com.ua/ua/pubs/id/6293

7. Про затвердження Порядку використання електронних замків з функцією GPS - GSM навігації Наказ Міністерства фінансів України 03.12.2012 N 1266 URL: https://zakon.rada.gov.ua/laws/show/z211012\#Text))

8. Митниця на замку. URL: https://hromadske.ua/posts/mytnytsya-na-zamku

\section{References}

1. Mytnyi kodeks Ukrainy. URL: zakon.rada.gov.ua/laws/show/4495-17\#Text (data zvernennia: 21.11.2021).

2. Pro zatverdzhennia Vymoh do kharakterystyk plomb spetsialnoho typu, vedennia yikh obliku ta zberihannia: Nakaz Ministerstva finansiv Ukrainy № 568 vid 29.10.2021 URL: https://mof.gov.ua/storage/files/\%D0\%9D\%D0\%B0\%D0\%BA\%D0\%B0\%D0\%B7(9).pdf

3. DSTU ISO 17712:2015. Vantazhni konteinery. Ushchilniuvachi mekhanichni. [Chynnyi vid 2016-0101].] Kyiv, 2001. 24 s. (Informatsiia ta dokumentatsiia). URL: http://online.budstandart.com/ua/catalog/docpage.html?id_doc $=96072$

4. E-seal worldwide container tracking inspection seal. URL: https://www.youtube.com/watch?v=wqz99bFYENY

5. Tranzytni vantazhi $\mathrm{z}$ elektronnymy zamkamy. URL: http://tr.sfs.gov.ua/media-ark/newsark/117473.html

6. Elektronni zasoby $\mathrm{z}$ funktsiieiu GPS-GSM-navihatsii: $\mathrm{i}$ kontroliuiut, $\mathrm{i}$ informuiut. URL: http://www.visnuk.com.ua/ua/pubs/id/6293

7. Pro zatverdzhennia Poriadku vykorystannia elektronnykh zamkiv z funktsiieiu GPS - GSM navihatsii Nakaz Ministerstva finansiv Ukrainy 03.12.2012 N 1266 URL: https://zakon.rada.gov.ua/laws/show/z211012\#Text))

8. Mytnytsia na zamku. URL: https://hromadske.ua/posts/mytnytsya-na-zamku 